\title{
Feasibility of Ni/Ti and Ni/GF cathodes in microbial electrolysis cells for hydrogen production from fermentation effluent: A step toward real application
}

\author{
Ibdal Satar ${ }^{1,2,3}$ (i) ｜ Mimi Hani Abu Bakar ${ }^{1}$ ｜ Wan Ramli Wan Daud ${ }^{1,4}$ | \\ Nazlina Haiza Mohd Yasin ${ }^{5}$ ｜ Mahendra Rao Somalu ${ }^{1}$ ～Byung Hong Kim ${ }^{1,6,7}$
}

${ }^{1}$ Fuel Cell Institute, Universiti Kebangsaan Malaysia, Bangi, Malaysia

${ }^{2}$ Department of Food Technology, Faculty of Industrial Technology, Universitas Ahmad Dahlan (UAD), Yogyakarta, Indonesia

${ }^{3}$ Department of Environmental Engineering, Institut Teknologi Yogyakarta (ITY), Yogyakarta, Indonesia

${ }^{4}$ Department of Chemical and Process Engineering, Faculty of Engineering and Built Environment, Universiti

Kebangsaan Malaysia, Bangi, Malaysia

${ }^{5}$ Department of Biological Sciences and Biotechnology, Faculty of Science and Technology, Universiti Kebangsaan Malaysia, Bangi, Malaysia

${ }^{6}$ Water Environment Research Centre, Korean Institute of Science and Technology, Seoul, Republic of Korea ${ }^{7}$ State Key Laboratory of Urban Water Resource and Environment, Harbin Institute of Technology, Harbin, China

\section{Correspondence}

Ibdal Satar, Department of Food

Technology, Faculty of Industrial

Technology, Universitas Ahmad Dahlan (UAD), Umbulharjo 55166, Yogyakarta, Indonesia.

Email: ibdalsatar@yahoo.com

\section{Funding information}

Ministry of Higher Education Malaysia, Grant/Award Number: FRGS/2/2013/ TK06/UKM/02/9; Universiti Kebangsaan Malaysia (UKM), Grant/Award Number: MI-2018-015

\begin{abstract}
Summary
The low cost, low over-potential loss, good catalytic properties for hydrogen evolution reaction (HER), high corrosion stability, commercially available, and could be applied in pH-neutral solution and ambient temperature are important properties for the cathode materials when it is applied in microbial electrolysis cell (MEC) technology. This study has two-pronged objectives: the first is to investigate the feasibility of titanium (Ti) and graphite felt (GF) coated with nickel $(\mathrm{Ni})$, and the second is to generate hydrogen from the fermentation effluent (FE). The electrodeposition (ED) method was used to deposit Ni catalyst onto $\mathrm{Ti}(\mathrm{Ni} / \mathrm{Ti})$ and $\mathrm{GF}(\mathrm{Ni} / \mathrm{GF})$ surfaces. The scanning electron microscopy (SEM) and energy dispersive X-ray (EDX) spectroscopy were used to characterize the cathode morphology and element composition. The catalytic properties of $\mathrm{Ni} / \mathrm{Ti}$ and $\mathrm{Ni} / \mathrm{GF}$ could be evaluated using the linear sweep voltammetry tests. The maximum volumetric $\mathrm{H}_{2}$ production rates of MEC using $\mathrm{Ni} / \mathrm{Ti}$ and $\mathrm{Ni} / \mathrm{GF}$ cathodes were obtained at $0.39 \pm 0.01$ and 0.33 $\pm 0.03 \mathrm{~m}^{3} \mathrm{H}_{2} \mathrm{~m}^{-3} \mathrm{~d}^{-1}$ respectively. The Ni/Ti and Ni/GF cathodes could be used as alternative cathodes while producing hydrogen from FE.
\end{abstract}

\section{KEYWOR D S}

alternative catalyst, dark fermentation effluent, electrodeposition (ED) method, hydrogen evolution reaction 


\section{1 | INTRODUCTION}

Biohydrogen production through anaerobic degradation can be generated from simple substrates such as acetate, ${ }^{1,2}$ glucose ${ }^{3}$ or complex substrates such as wastewater $^{4}$ and dark fermentation effluent (FE) ${ }^{5,6}$ In a microbial electrolysis cell (MEC) system, the electroactive bacteria $(\mathrm{EAB})$ generate the currents (electrons) and protons from substrate. ${ }^{2}$ The EAB such as Shewanella oneidensis, Pseudomona aeroginosa ${ }^{7}$ or mixed-culture, consume(s) organic substrates, which produce electrons, protons, and release carbon dioxide $\left(\mathrm{CO}_{2}\right)$. The electrons are transferred by EAB to the anode material while the protons are released to the anolyte. The electrons and protons were then move toward the cathode to produce hydrogen. In theory, a $0.2 \mathrm{~V}$ of the additional voltage $\left(E_{\text {ap }}\right)$ should be supplied into the system to overcome endothermic drawback of $-0.414 \mathrm{~V}$ during hydrogen production. ${ }^{8}$ However, an additional voltage of $0.3 \mathrm{~V}$ or higher $E_{\text {ap }}$ is required to overwhelm the over-potential effects on electrode. These documented voltage input is much more lower when compared to that in water splitting method which necessitate up to the voltage range of $1.8-2.0 \mathrm{~V} .^{9}$

The use of expensive material as cathode such as platinum (Pt) give a major drawback in the MEC technology due to its cost and environmental problem. Pt has been widely used as cathode or catalyst in many applications including bio-electrochemical technologies. In general, Pt catalyst is coated onto substrates such as carbon cloth ${ }^{9-11}$ or carbon paper ${ }^{12}$ using Nafion solution as a binder where these two materials (Pt and Nafion) are expensive. ${ }^{13}$ In addition, Pt substances are easily become poisonous when act with the chemicals presented in wastewater such as sulfide. ${ }^{9,14}$ The presence of microorganisms may be able to convert Pt substances into dangerous materials. ${ }^{15}$ These facts become important reasons to explore the feasibility of alternative materials such as non-precious metals.

Feasibility of non-precious metals have been investigated for hydrogen production in MEC application. The non-precious metals in the first row of periodic table show promising properties such as their good stabilty, low overpotential loss, commercially available, cheap, and having low toxicity to living organisms. Among of them, nickel $(\mathrm{Ni})$ becomes the best option because the catalytic properties for hydrogen evolution reaction $(\mathrm{HER})^{16}$ is relatively high. In addition to the high corrosion stability, ${ }^{1}$ also, Ni can be applied effectively at ambient temperature condition and $\mathrm{pH}$-neutral. ${ }^{17}$ The application of Ni-based cathodes in MEC have widely been reported by researchers, for instance, $\mathrm{Ni}$ foam
$(\mathrm{NF}),{ }^{18}$ alloy, ${ }^{2,19} \mathrm{Ni}$ mesh (NM),${ }^{20}$ Ni-based composites ${ }^{21}$ and Ni-based catalyst. ${ }^{17}$

In addition to the cathode material, $\mathrm{Ni}$ can also be used as HER catalyst. For instance, different forms of nickel alloys (ie, NiFe, NiMo, NiW, NiFeMo, NiFeP, $\mathrm{NiCr}$ ) and Ni particles can be electrochemically or chemically deposited onto stainless steel (SS), nickel alloy $(\mathrm{Ni625/Nix})^{2}$ and nickel foam (NF). ${ }^{17}$ The electrochemical processes are generally known as the electrodeposition (ED) method. These cathodes also show the good stability in long term operation. Based on these reports, Ni-based materials show the promising properties for cathode and or catalyst for hydrogen production in MEC system. Also, it was well known that the price of $\mathrm{Ni} / \mathrm{Ti}$ (36.49 USD/unit) and Ni/GF (15.69 USD/unit) cathodes are relative cheaper compared with platinum-based cathodes such as Ti/Pt (40.95 USD/unit) and Pt/GF (25.04 USD/unit), ${ }^{22}$ respectively.

It is well known that the dark fermentation (DF) is an efficient process to produce hydrogen, but a substantial amount of chemical oxygen deman (COD) remains in the effluent. The use of dark FE as the substrate in a MEC leads to the nearly complete conversion of COD into hydrogen. According to our previous report ${ }^{23}$ that the dark FE was composed by volatile fatty acids (VFAs) such as acetic, lactic, malic, butyric, and propionic. Among these VFAs, acetic is more dominant compared to the other one. As is known to all, the acetic is a simple organic acid that can be easily converted into hydrogen gas by EAB in MEC system. Therefore, FE becomes an interesting substrate in MEC for generating more hydrogen gas as value-added product with a complete conversion of COD into hydrogen. In addition, FE can also be assumed as a model substrate to represent the real wastewater, thus, this study was a step toward real application of MEC.

Both Ni/Ti and Ni/GF have only been used as cathode material in MFC as demonstrated in our previous study ${ }^{24}$ However, no reports were documented using $\mathrm{Ni} / \mathrm{Ti}$ and $\mathrm{Ni} / \mathrm{GF}$ as cathode material in MEC to produce hydrogen from FE. Inspired on all facts, this study try to investigate the performance of $\mathrm{Ni} / \mathrm{Ti}$ and $\mathrm{Ni} / \mathrm{GF}$ cathodes under $\mathrm{pH}$-neutral $(\mathrm{pH}=7.0)$ condition at room temperature $\left(\sim 26^{\circ} \mathrm{C}\right)$ using $\mathrm{FE}$ as anolyte in comparison with the control (Pt/GF). Thus, the study could describe the feasibility of MEC with $\mathrm{Ni} / \mathrm{Ti}$ and $\mathrm{Ni} / \mathrm{GF}$ cathodes to generate hydrogen and to treat the effluent of fermentation. To evaluate their performances, several parameters such as the maximum volumetric hydrogen production rate, cathodic hydrogen recovery, energy efficiency achieved with both cathodes are evaluated. 


\section{2 | MATERIALS AND EXPERIMENTAL METHODS}

\section{1 | Preparation of cathodes}

In this study, graphite felt (GF) and titanium foam (Ti) were used as raw materials for cathode while nickel (Ni) as catalyst. The dimensions of GF and Ti were prepared in size (long $\times$ width) of $5 \mathrm{~cm} \times 5 \mathrm{~cm}$ and $3.5 \mathrm{~cm} \times 3.5 \mathrm{~cm}$, respectively. The dimension of $\mathrm{Ti}$ was smaller than GF due to material availability obstacle. Both GF and Ti materials were cleaned before ED processes were conducted. The GF was deep into $0.1 \mathrm{M} \mathrm{HCl}$ for 1 hour and rinsed with distilled water thrice. Then, the material was deep into $0.1 \mathrm{M} \mathrm{NaOH}$ for 1 hour and rinsed with distilled water thrice to neutralize the GF material. Meanwhile, Ti material was cleaned with ethanol and rinsed with deionized water (DW) thrice. Lastly, both GF and Ti materials were dried in oven overnight at $80^{\circ} \mathrm{C}$.

Then, GF and Ti surfaces were deposited with $\mathrm{Ni}$ using ED method and were then denoted as Ni/GF and $\mathrm{Ti} / \mathrm{Ni}$, respectively. The Ni ED process was performed in an electrochemical cell as described by Satar et al. ${ }^{24} \mathrm{NF}$ was used as anode while Ti or GF as cathode. Acidic solution $\left(\mathrm{pH}=2\right.$, adjusted with $\left.\mathrm{H}_{2} \mathrm{SO}_{4}\right)$ containing $12 \mathrm{mM}$ $\mathrm{NiSO}_{4}$ and $20 \mathrm{mM}\left(\mathrm{NH}_{4}\right)_{2} \cdot \mathrm{SO}_{4}$ was used as electrolyte. The direct current (DC) power source (PS) (Keithley $2230-30-1$, US $)^{1}$ was used to supply the voltage $(20 \mathrm{~V})$ into the electrochemical cell. During the ED process, the electrolyte was heated upto $55^{\circ} \mathrm{C}$ and stirred $(350 \mathrm{rpm})$ using a magnetic bar for 30 minutes. Lastly, the morphologies and element compositions of $\mathrm{Ni} / \mathrm{GF}$ and $\mathrm{Ni} / \mathrm{Ti}$ were analyzed using scanning electron microscopy (SEM) and energy dispersive X-ray spectroscopy (EDX) respectively. As a cathode control, GF coated with $0.5 \mathrm{mg} \mathrm{cm}^{-2} \mathrm{Pt}$ catalyst (denoted as Pt/GF in this study) was prepared by chemical process using Nafion solution as a binder.

\section{2 | Microbial electrolysis cell (MEC) construction and operation}

A photograph (Figure 1A) and schematic (Figure 1B) of dual-chamber MEC reactor was fabricated from solid block acrylic. The dimensions of both anode and cathode compartments were prepared in size of $5 \mathrm{~cm}$ long $\times 5 \mathrm{~cm}$ high $\times 3 \mathrm{~cm}$ width (active volume $50 \mathrm{~cm}^{3}$ ). The GF (without catalyst) was used as anode while $\mathrm{Ni} / \mathrm{Ti}$ or $\mathrm{Ni} / \mathrm{GF}$ as cathode. The GF anode was enriched with EAB using anolyte from MFC reactor that have been operating for 12 months. $^{25}$ The FE was used as substrate during the enrichment and production process at the anode. This stage, the anode was under biotic condition. Meanwhile, a $100 \mathrm{mM} \mathrm{KCl}$ solution $(\mathrm{pH}=7.0$ ) was used as catholyte. ${ }^{26}$ The cathode compartment was operated under abiotic conditions in order that no biofilm is formed in the cathode. To maintain the cathode in an abiotic conditions, cation exchange membrane (CEM 7000s) was used to separate the anode and cathode chambers, thus, there were no microorganisms cross over into the cathode.

All MECs were run in a fed batch mode at ambient temperature of $26^{\circ} \mathrm{C}$. An additional voltage was
(A)

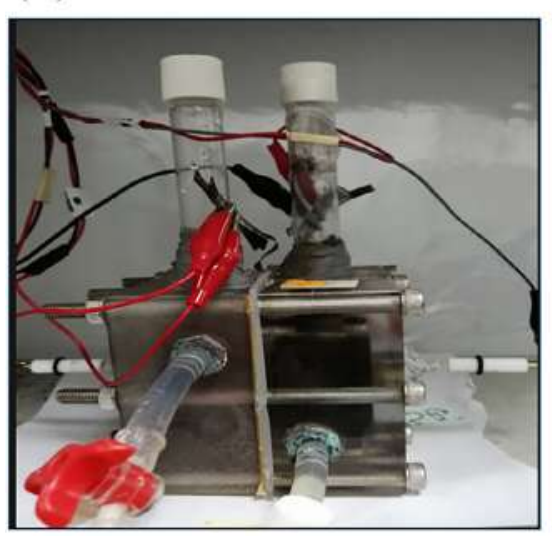

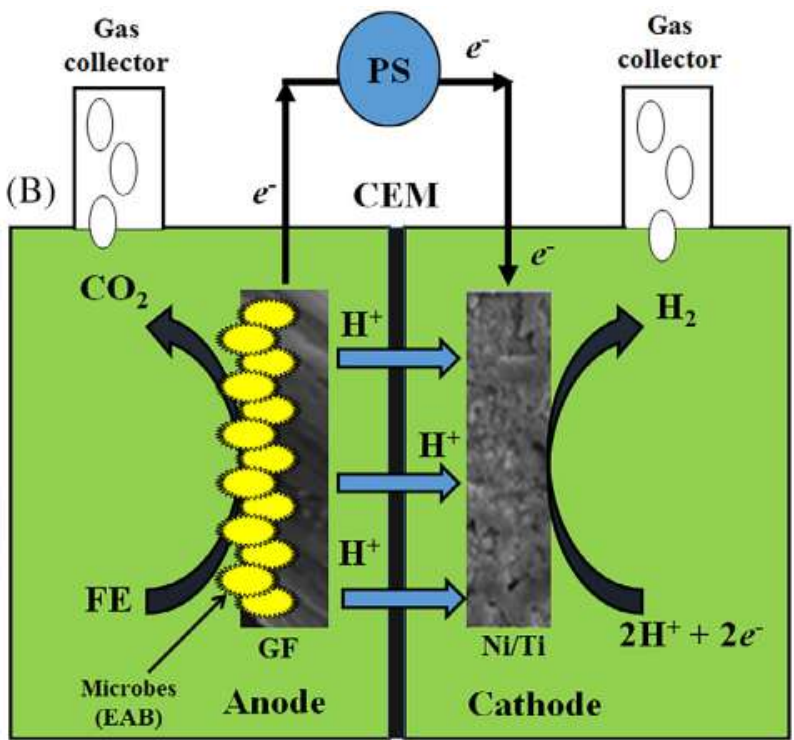

FI G U RE 1 Photograph A, and schematic B, of dual chamber MEC construction having an anode, cathode, separator (CEM, CMI 7000s) and gas collector [Colour figure can be viewed at wileyonlinelibrary.com] 
supplemented by a PS (Keithley 2230-30-1 Triple Channel DC Power Supply, US) into the reactors. The reactors were refreshed with fresh electrolytes (anolyte and catholyte) after 24 hours. The high purity nitrogen (99.9\%) was purged into the reactors for 5 minutes to maintain the anaerobic conditions. After the reactors achieved the constant current production and biogas volume after three consecutive feeding cycles, the applied voltage $\left(E_{\text {ap }}\right)$ was increased to a higher voltage (in the range of 0.5-1.0 V).

\section{3 | Surface morphology and catalytic performance analysis}

The morphologies and element compositions of cathodes were characterized by using the SEM and EDX. The SEM-EDX analysis were performed by using JEOL JSM 5800 as described by Satar et al. ${ }^{24}$ Initially, the cathodes were cut with size of $10 \mathrm{~mm} \times 10 \mathrm{~mm}\left(100 \mathrm{~mm}^{2}\right)$ and washed with deionized water (DW) for three times to remove impurities and then dried in the oven at $80^{\circ} \mathrm{C}$ overnight. Lastly, the cathode surface morphology and chemical compositions were analyzed using JEOL JSM 5800.

The catalytic performance can be investigated by using the Linear Sweep Voltammetry (LSV) tests. The LSV tests were performed using a PotentiostatGalvanostat (Autolab PGSTAT128N, Netherlands) in a chamber with three-electrode configuration with scan rate of $25 \mathrm{mV} \mathrm{s}^{-1}$. The anode (Pt rod) was used as counter electrode (CE) while the cathode as working electrode (WE) and $\mathrm{Ag} / \mathrm{AgCl}$ as the reference electrode (RE). The LSV tests should be performed to generate the voltammograms of the cathodes. To obtain the Tafel plot, voltammograms (scans) were transformed into the current density $(J)$ as a function of the potential (V) as described by Salembo et al. ${ }^{2}$ From the Tafel plot, the slopes, $y$-intercepts, and $\mathrm{V}$-intersects were used to predict the catalytic performance.

\subsection{Gas analysis and calculations}

The produced biogas was collected using a $20 \mathrm{~mL}$ vial containing acidic solution $\left(2.5 \% \mathrm{H}_{2} \mathrm{SO}_{4}\right)$. The biogas compositions were analyzed by using a gas chromatography (GC HP-4890D series, USA) equipped with stainless tubing columns (Altech Molesieve 5A 80/100) and thermal conductivity detector (TCD). The mixture of helium $(\mathrm{He})$ and air were used as a carrier gas.

In principle, as described by Logan et $\mathrm{al}^{9}$ and Salembo et $\mathrm{al}^{2}$ that the MEC performance is evaluated based on the parameters such as $\mathrm{H}_{2}$ yield, $\mathrm{H}_{2}$ recovery, and maximum volumetric $\mathrm{H}_{2}$ production rates, energy recovery, and volumetric density. ${ }^{1,9}$ Equation (1) is used to calculate the $\mathrm{H}_{2}$ yield $\left(Y_{\mathrm{H} 2}, \mathrm{~mL} \mathrm{H}_{2} \mathrm{~mL}^{-1} \mathrm{COD}\right)$ based on the COD removal, as follows:

$$
Y_{H 2}=\frac{n_{H 2} M_{H 2}}{V_{l} \Delta C O D},
$$

where $M_{H_{2}}$ is the molecular mass of $\mathrm{H}_{2}\left(2 \mathrm{~g} \mathrm{~mol}^{-1}\right), V_{l}$ is the volume $(\mathrm{L})$ of substrate in anode chamber, $\Delta \mathrm{COD}$ is the amount of the COD removal in $\mathrm{g} \mathrm{L}^{-1}$. The $n_{\mathrm{H} 2}$ is the actual amount of $\mathrm{H}_{2}$ moles (mol) generated from the reactor, calculated by using ideal gas law (Equation 2):

$$
n_{H 2}=\frac{P V_{H 2}}{R T},
$$

where $P$ and $V_{H^{2}}$ are gas pressure (1 atm) and volume of $\mathrm{H}_{2}$ generated from the reactor (L). The $R$ and $T$ are gas constant $\left(0.0821 \mathrm{~L} \mathrm{~atm} \mathrm{~K}^{-1} \mathrm{~mol}^{-1}\right)$ and absolute temperature $(303 \mathrm{~K})$, respectively.The $\mathrm{H}_{2}$ recovery is calculated based on the substrate $\left(r_{H 2[S]}\right)$ as shown in Equation (3). The $\mathrm{H}_{2}$ recovery is the ratio of the actual amount of $\mathrm{H}_{2}$ moles produced from the reactors $\left(n_{H_{2}}\right)$ compared to the maximum theoretical number $\mathrm{H}_{2}$ moles produced based on substrate $\left(n_{H_{2}}\left[{ }_{[S]}\right)\right.$. The theoretical number of $\mathrm{H}_{2}$ moles produced $\left(n_{H_{2}}[S]\right)$ is calculated by using Equation (4), as follows:

$$
\begin{gathered}
r_{H 2[S]}=\frac{n_{H 2}}{n_{H 2}[S]} \\
n_{H 2[S]}=\frac{b_{e O_{2}} V_{S} \Delta C O D}{2\left(M_{O 2}\right)},
\end{gathered}
$$

where $b_{e \mathrm{O} 2}$ Equation (4) and $M_{\mathrm{O} 2}\left(32 \mathrm{~g} \mathrm{~mol}^{-1}\right)$ are the number of electrons exchanged per mole $\mathrm{O}_{2}$ and the molecular weight of $\mathrm{O}_{2}$. The $V_{\mathrm{s}}$ is volume of the anolyte in anode chamber $(50 \mathrm{~mL})$ and 2 is the number of electrons per moles $\mathrm{H}_{2}$. The amount of $\mathrm{H}_{2}$ moles that can be recovered based on the measured current from experiment $\left(n_{H 2}[C E]\right)$ is calculated using Equation (5), as follows:

$$
n_{H 2[C E]}=\frac{\int_{0}^{t} I \mathrm{~d} t}{2 F},
$$

where $I(\mathrm{~A})$ is the current calculated from the voltage (volt) across the external resistor used $\left(R_{e x}=1 \Omega\right)$ and $\mathrm{d} t$ is the time interval for data collection. The $F$ is Faraday's constant $\left(96485 \mathrm{C} \mathrm{mol}^{-1}\right.$ ) and 2 is the number of electrons per moles $\mathrm{H}_{2}$. Equation (6) is used to calculate the columbic $\mathrm{H}_{2}$ recovery $\left(r_{H 2[C E]}\right)$, as follows: 


$$
r_{H 2[C E]}=\frac{n H_{2}[C E]}{n H_{2}[S]}=C E \text { or } \mathrm{CE}=\frac{n H_{2}[C E]}{n H_{2}[S]}=\frac{r H_{2}[S]}{r H_{2}[c a t]} .
$$

Based on Equation (7), the cathodic $\mathrm{H}_{2}$ recovery $\left(r_{H 2}\right.$ [cat]) can be defined as a fraction from the total amount of electrons in the cathode that can be converted to $\mathrm{H}_{2}$. The overall $\mathrm{H}_{2}$ recovery $\left(r_{H_{2}}[\right.$ [tot] $)$ is determined using Equation (8). The total amount of recovered $\mathrm{H}_{2}$ moles versus the theoretical value is known as the efficiency of $\mathrm{H}_{2}$ production.

$$
\begin{gathered}
r_{H 2[c a t]}=\frac{n H_{2}}{n H_{2}[C E]} \\
r_{H 2[t o t]}=r_{H 2[c a t] \times} \mathrm{CE}=\frac{n H_{2}}{n H_{2}[S]} .
\end{gathered}
$$

The energy efficiency relative $\left(\eta_{\mathrm{E}}\right)$ refers to the ratio of energy content of $\mathrm{H}_{2}$ produced to the input electrical energy. The $\eta_{\mathrm{E}}$ is calculated based on the Equation (9), as follows:

$$
n_{E}=\frac{W H_{2}}{W_{E}}=\frac{n H_{2} x \Delta H H_{2}}{\sum_{1}^{n}\left(I E_{a p} \Delta t-I^{2} R_{e x} \Delta t\right)},
$$

where $W_{H 2}(\mathrm{~kJ})$ is the energy produced by $\mathrm{H}_{2}$ based on the total amount of produced $\mathrm{H}_{2}$ moles $\left(\mathrm{nH}_{2}\right)$ multiplied by the energy content of $\mathrm{H}_{2}\left(\Delta H_{H 2}\left(285.83 \mathrm{~kJ} \mathrm{~mol}^{-1}\right)\right.$. $W_{E}(\mathrm{~kJ})$ is the total amount of energy added into the circuit by the PS minus the losses across the external resistor $\left(R_{\text {ex }}, 1 \Omega\right)$ and $E_{\text {ap }}(\mathrm{V})$ is the applied voltage to the reactors. The number of substrate moles $\left(n_{s}\right)$ consumed during experiment based on COD removal is determined by Equation (10), as follows:

$$
n_{S}=\frac{\Delta C O D V_{l}}{M_{S}},
$$

where $M_{S}$ is molecular weight of substrate. The energy efficiency relative to the substrate $\left(\eta_{S}\right)$ is calculated using Equation (11), as follows:

$$
n_{S}=\frac{W H_{2}}{W_{S}}=\frac{n_{H_{2}} \Delta H_{H_{2}}}{n_{H_{2}} \Delta H_{S}},
$$

where $\Delta H_{s}$ is heat combustion for substrate. The overall energy recovery $\left(n_{E+S}\right)$ can be calculated using Equation (12), as follows:

$$
n_{E+S}=\frac{W H_{2}}{W_{E}+W_{S}} .
$$

The maximum volumetric $\mathrm{H}_{2}$ production rate, $Q_{\max }$ $\left(\mathrm{m}^{3} \mathrm{H}_{2} \mathrm{~m}^{-3} \mathrm{~d}^{-1}\right)$ directly corresponds to the volumetric current density. ${ }^{9}$ Theoretically, the $Q_{\max }$ can be calculated using Equation (13), as follows:

$$
Q=3.68 \times 10^{-5} I_{V} \operatorname{Tr}_{H_{2[c a t}},
$$

where $3.68 \times 10^{-5}$ is a constant that includes the Faraday's constant (96485 $\mathrm{C} \mathrm{mol}^{-1}$ ), pressure (1 atm), and unit conversion. The volumetric current density $\left(I_{V}\right.$, $\mathrm{Am}^{-3}$ ) is averaged over 4-hours period of maximum current production and divided by the volume of substrate, and $T(\mathrm{~K})$ is the temperature of experiment.

\section{3 | RESULTS AND DISCUSSION}

\section{1 | Conditions of electrolytes before and after MEC operation}

Dual chamber MECs were constructed by using GF as anode, while $\mathrm{Ni} / \mathrm{Ti}$ or Ni/GF as cathodes and CEM (CMI 7000s) as separator. Before and after MEC operations, the electrolyte properties such as $\mathrm{COD}, \mathrm{pH}$, and conductivity were evaluated. The change in the properties could elaborate the effect of electrolyte conditions on MEC performances. The change in $\mathrm{pH}$ and conductivity were shown in Table 1 . The $\mathrm{pH}$ value refers to the concentration of protons $\left[\mathrm{H}^{+}\right]$in electrolyte. The high $\left[\mathrm{H}^{+}\right]$concentration results the low $\mathrm{pH}$ value. On the other hand, the electrolyte conductivity is closely related to the amount of charged ions in the solution.

The high concentration of proton $\left[\mathrm{H}^{+}\right]$in the anolyte was due to the low transfer efficiency of protons from anolyte to catholyte, ${ }^{27,28}$ consequently, the $\mathrm{pH}$ value was low. Meanwhile, the decrease in conductivity might be due to the most of VFAs ions were converted into carbon dioxide $\left(\mathrm{CO}_{2}\right)$, and/or the most of cations were move toward catholyte. Overall, the $\mathrm{pH}$ values and conductivities of anolytes were decreased (Table 1). For example MEC with $\mathrm{Pt} / \mathrm{GF}$, the $\mathrm{pH}$ value and conductivity were decreased from $7.01 \pm 0.01$ to $5.73 \pm 0.02$ and 15.86 \pm 0.03 to $13.01 \pm 0.02 \mathrm{mScm}^{-1}$, respectively. On the other hand, the $\mathrm{pH}$ and conductivity of catholyte were increased from 7.01 to 12.20 and $13.08 \pm 0.02$ to 18.25 $\pm 0.02 \mathrm{mScm}^{-1}$, respectively. These facts might due to the accumulation of charged ions in the catholyte. The increase in $\mathrm{pH}$ might due to the amount of hydroxide ions in the catholyte as resulted the water electrolysis. ${ }^{29}$ As shown in Equation (20), the water was electrolyzed by currents to produce protons and hydroxide ions. Since the current was simultaneously supplied into the reactor, the protons were then reduced to form hydrogen gas while hydroxide ions were accumulated in catholyte. 


\begin{tabular}{|c|c|c|c|c|}
\hline \multirow[b]{2}{*}{ Cathodes } & \multicolumn{2}{|l|}{$\mathbf{p H}$} & \multicolumn{2}{|c|}{ Conductivity $\left(\mathrm{mScm}^{-1}\right)$} \\
\hline & Anolyte & Catholyte & Anolyte & Catholyte \\
\hline \multicolumn{5}{|c|}{ At the beginning of MEC run } \\
\hline $\mathrm{Pt} / \mathrm{GF}$ & $7.01 \pm 0.01$ & $7.01 \pm 0.01$ & $15.86 \pm 0.03$ & $13.08 \pm 0.02$ \\
\hline $\mathrm{Ni} / \mathrm{Ti}$ & $7.01 \pm 0.01$ & $7.01 \pm 0.01$ & $15.86 \pm 0.03$ & $13.08 \pm 0.02$ \\
\hline $\mathrm{Ni} / \mathrm{GF}$ & $7.01 \pm 0.01$ & $7.01 \pm 0.01$ & $15.86 \pm 0.03$ & $13.08 \pm 0.02$ \\
\hline \multicolumn{5}{|c|}{ At the end of MEC run } \\
\hline $\mathrm{Pt} / \mathrm{GF}$ & $5.73 \pm 0.02$ & $12.20 \pm 0.02$ & $13.01 \pm 0.02$ & $18.25 \pm 0.02$ \\
\hline $\mathrm{Ni} / \mathrm{Ti}$ & $6.02 \pm 0.01$ & $12.00 \pm 0.01$ & $13.49 \pm 0.02$ & $17.00 \pm 0.02$ \\
\hline $\mathrm{Ni} / \mathrm{GF}$ & $5.78 \pm 0.02$ & $11.90 \pm 0.02$ & $13.81 \pm 0.02$ & $15.50 \pm 0.02$ \\
\hline
\end{tabular}

T A B LE 1 Summary of electrolyte conditions at the beginning and at the end of MEC run at $1.0 \mathrm{~V}$ of $E_{\mathrm{ap}}=1.0 \mathrm{~V}$ for $48 \mathrm{~h}$
These facts illustrate that the $\mathrm{pH}$ and conductivity (correspond to resistance of electrolyte) are contributed to the HER at the cathode. The $\mathrm{pH}$ affects the EAB ability to generate protons while the conductivity responsible on electron transfer. Due to the HER depend on the proton supply from anolyte to undergo reduction at the cathode,$^{30}$ so the effect of $\mathrm{pH}$ on hydrogen production is more significant compared to the electrolyte conductivity. ${ }^{31}$ In addition to the $\mathrm{pH}$ and conductivity, the additional voltage and catalyst are needed to overcome the endothermic barrier. In general, the additional voltage in the range of 0.5-1.0 V was applied into the reactor using Pt or other non-noble metals as the catalyst. ${ }^{18}$ Usually, metal based cathodes or catalysts are quite sensitive to the change in $\mathrm{pH}$ of catholyte. ${ }^{32}$ Therefore, the $\mathrm{pH}$ of catholyte must be considered during MEC operation.

In this study, $\mathrm{FE}$ was used as anolyte while $\mathrm{KCl}$ as catholyte. $\mathrm{FE}$ degradation and $\mathrm{H}_{2}$ formation can be described based on the VFAs reactions at the anode and hydrogen production at the cathode. In these stages, $\mathrm{H}^{+}$, $e^{-}$and $\mathrm{CO}_{2}$ productions were generated by $\mathrm{EAB}$ at the anode while $\mathrm{H}_{2}$ generated via HER at the cathode. As mentioned above, the FE composed by a various VFA such as acetic, propionic, butyric lactic, and malic. It was well known that the acetate was degraded more rapidly compared to the other one. ${ }^{33}$ Generally, the VFAs were oxidized by microorganisms (ie, EAB) to produce currents, proton, and carbon dioxide. To better understand the FE oxidation in the anode, the mechanisms of each VFA can generally be described as follows:

Anode reaction;

$$
\begin{aligned}
& \text { Acetate } \mathrm{C}_{2} \mathrm{H}_{4} \mathrm{O}_{2}+2 \mathrm{H}_{2} \mathrm{O} \stackrel{E A B}{\rightarrow} 8 \mathrm{H}^{+}+8 e^{-}+2 \mathrm{CO}_{2} \\
& \text { Propionate } \mathrm{C}_{3} \mathrm{H}_{6} \mathrm{O}_{2}+4 \mathrm{H}_{2} \mathrm{O} \stackrel{E A B}{\longrightarrow} 14 \mathrm{H}^{+}+14 e^{-}+3 \mathrm{CO}_{2}
\end{aligned}
$$

Butyrate; $\mathrm{C}_{4} \mathrm{H}_{8} \mathrm{O}_{2}+6 \mathrm{H}_{2} \mathrm{O} \stackrel{E A B}{\rightarrow} 20 \mathrm{H}^{+}+20 e^{-}+4 \mathrm{CO}_{2}$

Lactate $\mathrm{C}_{3} \mathrm{H}_{6} \mathrm{O}_{3}+3 \mathrm{H}_{2} \mathrm{O} \stackrel{E A B}{\longrightarrow} 12 \mathrm{H}^{+}+12 e^{-}+3 \mathrm{CO}_{2}$

Malate $\mathrm{C}_{4} \mathrm{H}_{6} \mathrm{O}_{5}+3 \mathrm{H}_{2} \mathrm{O} \stackrel{E A B}{\longrightarrow} 12 \mathrm{H}^{+}+12 e^{-}+4 \mathrm{CO}_{2}$

Cathode reaction;

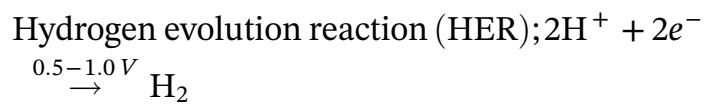

Water electrolysis; $2 \mathrm{H}_{2} \mathrm{O}+2 \mathrm{e}^{-}$

$$
\stackrel{0.5-1.0 \mathrm{~V}}{\Leftrightarrow} 2 \mathrm{H}^{+}+2 \mathrm{OH}^{-}+2 \mathrm{e}^{-} \stackrel{0.5-1.0 V}{\rightarrow} \mathrm{H}_{2}+2 \mathrm{OH}^{-} \text {. }
$$

The EAB activities in the anode compartment could be identified by measuring the change in COD. The high COD removal $(\triangle \mathrm{COD})$ indicates the high amount of substrate consumed by $\mathrm{EAB}$, which contributes to the hydrogen production. ${ }^{34}$ From the Figure 2, MEC with $\mathrm{Pt} / \mathrm{GF}$ shows the highest $\mathrm{COD}_{\text {removal }}(43.2 \pm 0.3 \%)$, followed by $\mathrm{Ni} / \mathrm{Ti}(40.1 \pm 0.5 \%)$ and $\mathrm{Ni} / \mathrm{GF}$ (37.8 $\pm 0.5 \%)$. Since high HER consumes the protons and electrons efficiently thus increasing cathode redox potential and proton gradient between the membrane. The increase in the cathode redox potential and proton gradient improve the conditions for a higher anode reaction. ${ }^{35}$ The CODs were gradually decreased along with the hydrogen production. These facts describe that the cathode materials were positively contributed to the COD removal. However, some part of COD was removed by other microorganisms not only by EAB but also particularly when mixed-culture is used as source of inoculum during the anode enrichment process. 


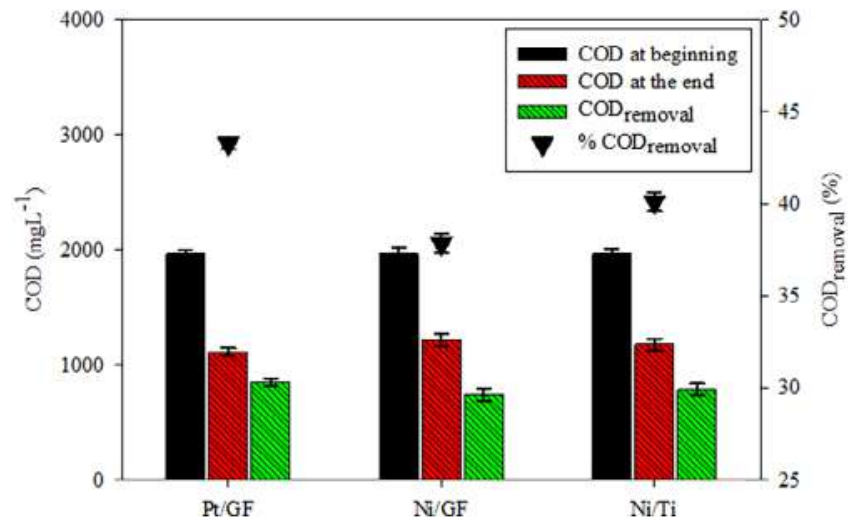

F I G U RE 2 The change in COD at the beginning and at the end of MEC operation [Colour figure can be viewed at wileyonlinelibrary.com]

Therefore, existence of other microorganisms should be accounted in the MEC systems.

\section{2 | Characterization of cathodes}

A simple and effective approach in the electrochemical depositions process is known as the ED technique using the DC method. The current flows in the electrolyte (solution) via the conducting anode and cathode. The ED technique homogeneously deposits and distributes the metal ions (cations) onto the surface or pores of material. ${ }^{36}$ To obtain the desired thickness and homogenous distribution, the several factors such as concentration and $\mathrm{pH}$ of solution, impurities present in the solutions, temperature, current density, operation time and agitation, should be controlled during the process. ${ }^{37}$ In this study, the simple $\mathrm{Ni}$ salt solution was used to deposit Ni particles. Based on the results, the ED technique successfully deposits $\mathrm{Ni}$ particles on the $\mathrm{Ti}$ and GF surfaces. These fact was proved by the SEM and EDX analysis. Based on the EDX analysis, there were no $\mathrm{Ni}$ element detected on the Ti and Ni surfaces before the ED process, in which the element compositions of $\mathrm{Ti}$ and GF were recorded as $100 \%$ of titanium and carbon, respectively. Meanwhile, the element compositions of the Ti and GF surfaces were changed after the ED process, in which the Ni compositions on $\mathrm{Ti}$ and GF surfaces were recorded as $36.6 \%$ and $48.6 \%$, respectively (Table 2). However, the other elements such as chlorine $(\mathrm{Cl})$, calcium $(\mathrm{Ca})$, iron $(\mathrm{Fe})$, potassium $(\mathrm{K})$, sodium $(\mathrm{Na})$, magnesium $(\mathrm{Mg})$, phosphorus $(\mathrm{P})$ and sulfur (S) were also obtained on the cathode surface. The presence of other elements might due to the presence of impurities in the solution which were contributed to the element compositions on the cathode surface. The
T A B L E 2 The selected element compositions on the cathode surfaces using EDX analysis

\begin{tabular}{|c|c|c|c|c|c|}
\hline \multirow[b]{2}{*}{ Cathodes } & \multicolumn{5}{|c|}{ Element compositions (\%) on the surfaces } \\
\hline & $\mathbf{C}$ & $\mathbf{N i}$ & $\mathbf{0}$ & $\mathbf{T i}$ & Others \\
\hline \multicolumn{6}{|l|}{ Before ED } \\
\hline GF & 100 & - & - & - & - \\
\hline $\mathrm{Ti}$ & - & - & - & 100 & - \\
\hline \multicolumn{6}{|c|}{ Start up MEC operation: after ED } \\
\hline $\mathrm{Ni} / \mathrm{GF}$ & 10.3 & 48.6 & 5.4 & - & 35.7 \\
\hline $\mathrm{Ni} / \mathrm{Ti}$ & - & 36.6 & 14.9 & 2.2 & 46.3 \\
\hline \multicolumn{6}{|c|}{ After 12 mo MEC operation } \\
\hline $\mathrm{Ni} / \mathrm{GF}$ & 66.4 & 2.9 & 23.5 & - & 7.2 \\
\hline $\mathrm{Ni} / \mathrm{Ti}$ & - & 5.2 & 41.9 & 14.3 & 38.6 \\
\hline
\end{tabular}

presence of impurities in the solution have negative effect on the current density, quality, and the growth morphology.

After 12 months of MEC operation, however, the $\mathrm{Ni}$ element compositions of $\mathrm{Ni} / \mathrm{Ti}$ and $\mathrm{Ni} / \mathrm{GF}$ surfaces were drastically decreased from $36.6 \%$ to $5.2 \%$ and $48.6 \%$ to $2.9 \%$, respectively. These cases might be due to the presence of other elements covered the cathode surface and the $\mathrm{Ni}$ particles detach from the cathode surfaces during MEC operation. Meanwhile, the increase in oxygen composition on $\mathrm{Ni} / \mathrm{Ti}$ and $\mathrm{Ni} / \mathrm{GF}$ surfaces might be due to the presence of oxide layer as a result of the electrolysis process at the cathode during the supply of the additional voltage into the reactors. In detail, MEC performance after 12 months will be discussed in Section 3.5.

The use of Ni catalyst to improve the cathode performances has also been studied by Salembo et $\mathrm{al}^{2}$ and Vij et al. ${ }^{16}$ For instance, Ni catalyst can be used to enhance the stainless steel (SS A286) performance. This fact was proved by the maximum volumetric hydrogen production rate $(Q)$ of $\mathrm{SS} \mathrm{A} 286 / \mathrm{Ni}$ (after deposited with $\mathrm{Ni}$ ) was increased from $0.01 \pm 0.0001$ to $0.76 \pm 0.16 \mathrm{~m}^{3} \mathrm{H}_{2} \mathrm{~m}^{-3} \mathrm{~d}^{-1}$. Whereas, this study shows the $Q$ of Ti and GF after deposited with Ni were obtained $0.39 \mathrm{~m}^{3} \mathrm{H}_{2} \mathrm{~m}^{-3} \mathrm{~d}^{-1}$ and $0.33 \mathrm{~m}^{3} \mathrm{H}_{2} \mathrm{~m}^{-3} \mathrm{~d}^{-1}$, respectively, which were comparable to that of $\mathrm{Pt} / \mathrm{CC}\left(0.4 \mathrm{~m}^{3} \mathrm{H}_{2} \mathrm{~m}^{-3} \mathrm{~d}^{-1}\right)$ reported by Sleutels et $\mathrm{al}^{38}$ (Table 4). However, the $Q$ of $\mathrm{Ni} / \mathrm{Ti}$ and Ni/GF were lower compared to that of SS A286/Ni. This fact might due to the difference substrate and configuration of MEC that were used during experiment. It is well known that the simple substrate (ie, acetate) easily consumed by EAB to generate hydrogen compared to the complex substrate (ie, $\mathrm{FE}^{41}$ In addition, the single chamber MEC generally shows better performance compared to that of the dual chamber MEC. ${ }^{42}$ 

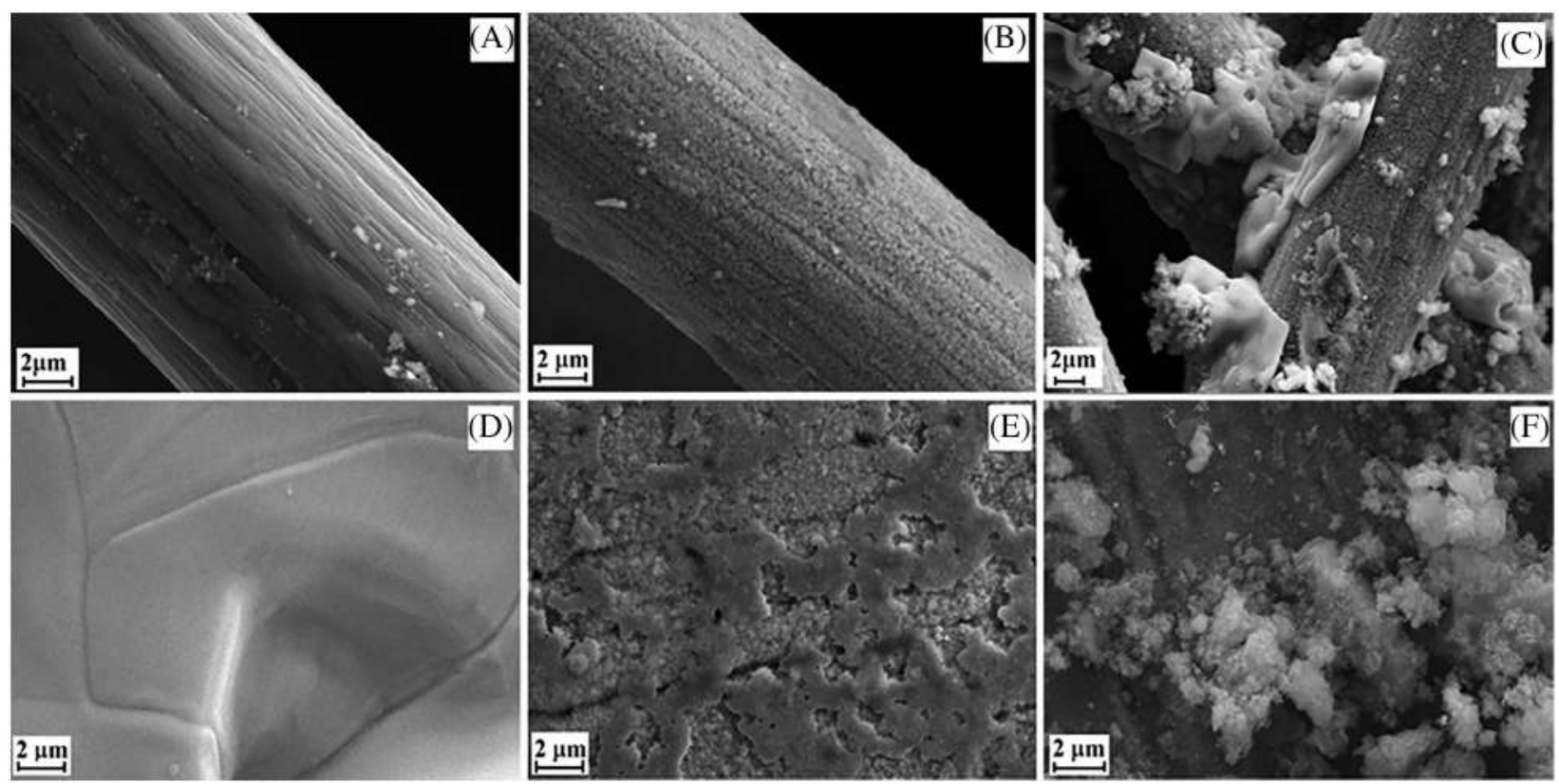

F I G U RE 3 SEM images for GF and titanium foam (Ti); the images for A, GF and D, Ti before deposited with Ni, B, GF and E, Ti after deposited with $\mathrm{Ni}, \mathrm{C}, \mathrm{Ni} / \mathrm{GF}$ and $\mathrm{F}, \mathrm{Ni} / \mathrm{Ti}$ at the end of MEC experiment (after 12 months)

Cathode's morphologies were successfully characterized by using SEM, as shown in Figure 3. The images of GF and Ti before ED were shown in Figure 3A,D while after elctrodeposition were shown in Figure 3B,E, respectively. Before ED, the surfaces of GF and Ti were clean and smooth. These images show the significant difference compared to that of GF and Ti after ED which were quite coarse and uneven. Compositions of main elements such as $\mathrm{C}, \mathrm{Ti}, \mathrm{Ni}$, and $\mathrm{O}$ on $\mathrm{GF}$ and $\mathrm{Ti}$ surfaces were listed in Table 2. Furthermore, Figure 3C,F were Ni/GF and Ni/Ti images after 12 months of MEC operation. The images show the cathode surfaces were much rougher than before and after ED. These cases might due to the cathode surfaces were covered by other components such as salt and/or oxide layer. The presence of salt on the cathode surfaces might be due to the use of catholyte $(\mathrm{KCl})$ although the cathodes were washed before SEM analysis. Also, oxygen (O) compositions on $\mathrm{Ni} / \mathrm{GF}$ and $\mathrm{Ni} / \mathrm{Ti}$ were increased from $5.4 \%$ to $23.5 \%$ and $14.9 \%$ to $41.9 \%$, respectively. The presence of other constituents (impurities) such as salt or oxide layer on the surface might contribute to the change in physicochemical properties of cathode (ie, ohmic resistance and charge transfers). These surface conditions affect the catalytic properties which leads to reduce electron flow, ${ }^{43}$ consequently, the hydrogen production was reduced (Section 3.5).

As shown in Table 2, the other elements were observed on the surfaces. Several elements such as $\mathrm{Ca}$, $\mathrm{Cl}, \mathrm{Fe}, \mathrm{K}, \mathrm{Na}, \mathrm{Mg}, \mathrm{Ca}, \mathrm{P}, \mathrm{Si}$, and $\mathrm{S}$ were obtained in low compositions (average $<4 \%$ for each element) on $\mathrm{Ni} / \mathrm{Ti}$ and $\mathrm{Ni} / \mathrm{GF}$ surfaces after 12 months of MEC operation. The presence of these elements might due to the impurities, the use of catholyte $(\mathrm{KCl})$ and diffusion of anolyte ions (ie, $\mathrm{Ca}, \mathrm{Mg}, \mathrm{Na}, \mathrm{P}$ ) from anode to cathode. These elements affect the cathode performance, therefore, to ensure the effect of each element on the catalytic properties, the extended study should be performed in the further work.

\section{3 | Catalytic properties of $\mathrm{Ni} / \mathrm{Ti}$ and Ni/GF}

In electrochemical analysis, LSV tests can generally be used to investigate the catalytic performance of materials. LSV tests generate the electrochemical data (voltammogram) that can be converted to Tafel plot. To obtain Tafel plot, the current density $\left(J, \mathrm{mAcm}^{-2}\right)$ is plotted as $y$-axis while the potential (V) as $x$-axis. Tafel plot's slopes and $y$-intercepts are useful to identify the electrocatlytic properties of the materials. Commonly, the steeper slopes and $y$-intercepts (at low current density) indicate a better electrocatalytic performance. ${ }^{1,44}$ As predicted the slope of $\mathrm{Pt} / \mathrm{GF}$ (Figure 4A) was steeper than $\mathrm{Ni} / \mathrm{Ti}$ (Figure 4B) and Ni/GF (Figure 4C). For this study, the slopes and $y$-intercepts of cathodes were presented in Table 3.

As shown in Table 3, the best cathode was Pt/GF with slope of $23.628 \mathrm{dec} \mathrm{mAcm}^{-2} \mathrm{~V}^{-1}$, followed by $\mathrm{Ni} / \mathrm{Ti}$ (22.962 dec $\mathrm{mAcm}^{-2} \mathrm{~V}^{-1}$ ) and Ni/GF (21.123 dec 

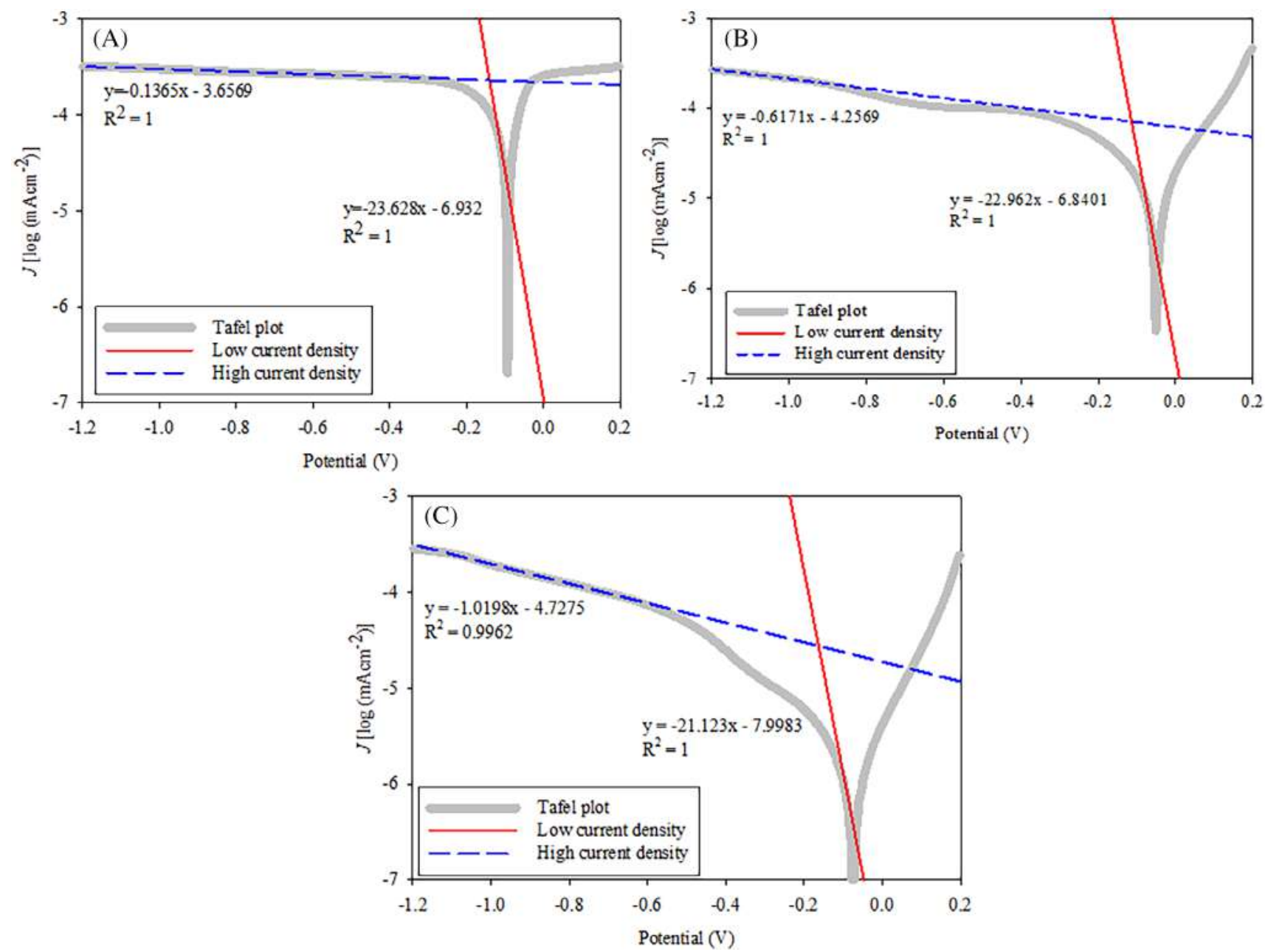

F I G U R E 4 Tafel plots for MEC for A, Pt/GF, B, Ni/Ti and C, Ni/GF cathodes [Colour figure can be viewed at wileyonlinelibrary.com]

T A B L E 3 The Tafel plots's slopes and y-intercepts for Pt/GF, Ni/Ti and Ni/GF cathodes

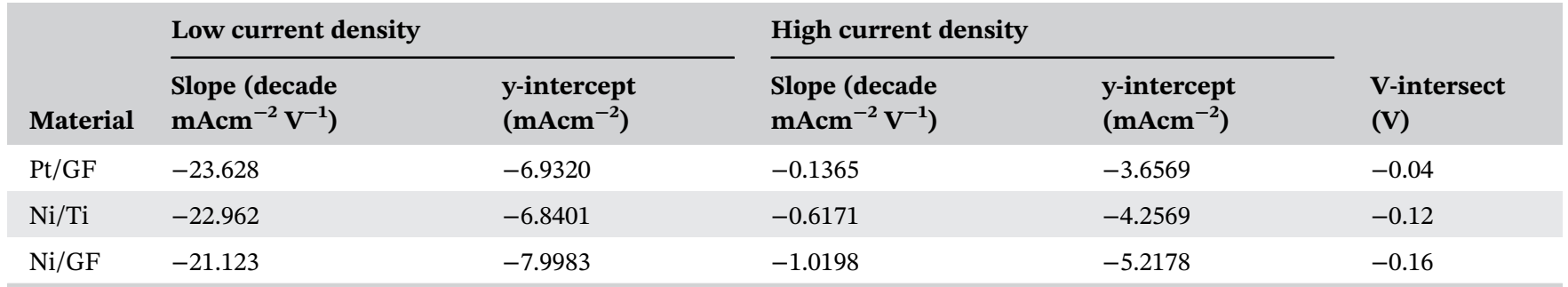

$\mathrm{mAcm}^{-2} \mathrm{~V}^{-1}$ ). Whereas, the $y$-intercept for Pt/GF was obtained $-6.9320 \mathrm{mAcm}^{-2}$ followed by $-6.8401 \mathrm{mAcm}^{-2}$ $(\mathrm{Ni} / \mathrm{Ti})$ and $-7.9983 \mathrm{mAcm}^{-2}(\mathrm{Ni} / \mathrm{GF})$. The V-intersect are the intersection between two linear regressions, which refers to the potential where cathodic reaction (ie, HER) occurs. The lower V-intersect indicates a better cathode performance due to HER started at the lower onset potential. From the Table 3, Pt/GF shows the lowest V-intersect $(-0.04 \mathrm{~V})$ followed by $\mathrm{Ni} / \mathrm{Ti}(-0.12 \mathrm{~V})$ and $\mathrm{Ni} / \mathrm{GF}(-0.16 \mathrm{~V})$. Therefore, the performance of MEC with $\mathrm{Pt} / \mathrm{GF}$ was better compared to that of $\mathrm{Ni} / \mathrm{Ti}$ and
$\mathrm{Ni} / \mathrm{GF}$. In terms of the maximum volumetric hydrogen production rate, however, $\mathrm{Ni} / \mathrm{Ti}$ was better compared to that of Pt metal as reported by Salembo et $\mathrm{al}^{2}$ while $\mathrm{Ni} / \mathrm{GF}$ better than that of $\mathrm{C} / \mathrm{Pt}$ as reported by Sleutels et $\mathrm{al}^{45}$ (Section 3.5). These facts indicate the $\mathrm{Ni} / \mathrm{Ti}$ and $\mathrm{Ni} / \mathrm{GF}$ can also be used as alternative cathodes in MEC application. Figure 4 shows the Tafel plots for Pt/GF (a), $\mathrm{Ni} / \mathrm{Ti}$ (b) and Ni/GF (c). The Tafel plots consisting two linear regressions; one at high current densities (dashed line) and one at low current densities (solid line). MEC should be theoretically operated at high current density 


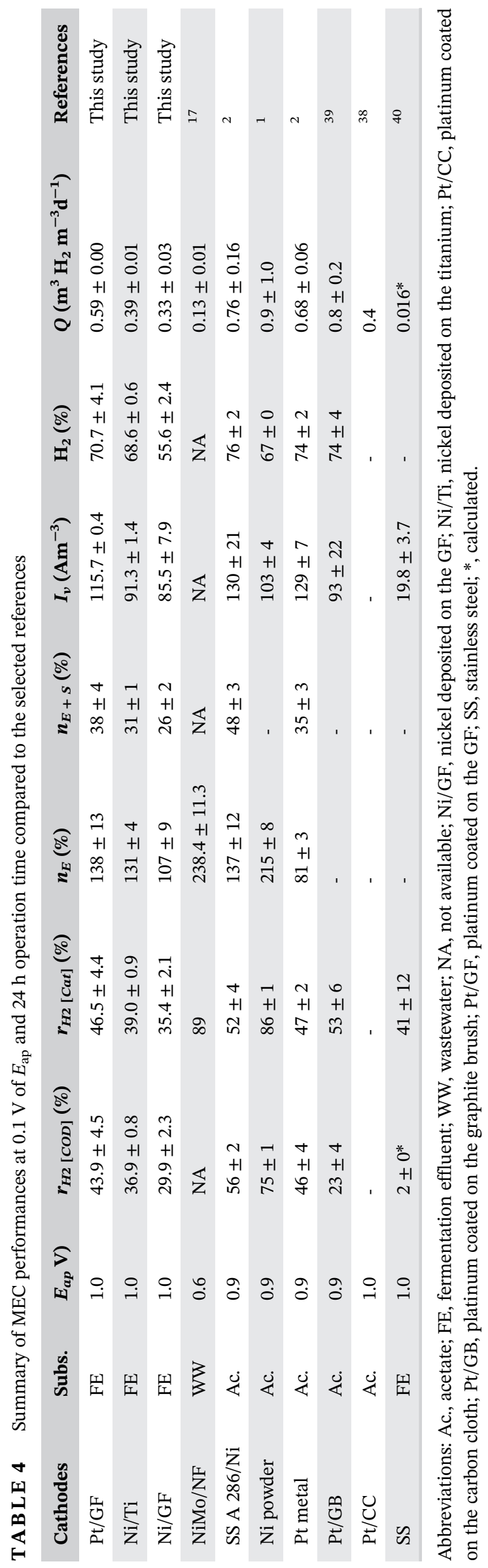

for a given potential. In addition, Tafel plots are useful for evaluating the kinetic parameters such as cathodic transfer coefficient $\left(\alpha_{c}=2\right)$ and the number of electrons $\left(n_{e}=1\right)$ for HER at the cathode. ${ }^{2,44}$

\section{4 | Maximum volumetric hydrogen production rate $(Q)$ for $\mathrm{Ni} / \mathrm{Ti}$ and $\mathrm{Ni} / \mathrm{GF}$}

The hydrogen production rate $(Q)$ is one of important parameters that can be used to evaluate the performance of MEC with $\mathrm{Ni} / \mathrm{Ti}$ and $\mathrm{Ni} / \mathrm{GF}$. As predicted, Pt/GF shows the highest $Q\left(0.59 \pm 0.00 \mathrm{~m}^{3} \mathrm{H}_{2} \mathrm{~m}^{-3} \mathrm{~d}^{-1}\right)$ followed by $\mathrm{Ni} / \mathrm{Ti}\left(0.39 \pm 0.01 \mathrm{~m}^{3} \mathrm{H}_{2} \mathrm{~m}^{-3} \mathrm{~d}^{-1}\right)$ and Ni/GF $(0.33$ $\left.\pm 0.03 \mathrm{~m}^{3} \mathrm{H}_{2} \mathrm{~m}^{-3} \mathrm{~d}^{-1}\right)$. The $Q$ of Ni/Ti and Ni/GF were comparable with that measured of the Pt-catalyzed carbon cloth (Pt/CC, $\left.0.4 \mathrm{~m}^{3} \mathrm{H}_{2} \mathrm{~m}^{-3} \mathrm{~d}^{-1}\right){ }^{38}$ The $Q$ of Ni/Ti and $\mathrm{Ni} / \mathrm{GF}$ were directly affected by the EAB activity. As discussed above, hydrogen production at the cathode is closely related to supply of protons by EAB from the anode. ${ }^{29}$ Low $\mathrm{pH}$ and conductivity affects the EAB activity, consequently the supply of protons from anode to undergo reduction through electrolysis at the cathode is low. ${ }^{46}$ Commonly, low $\mathrm{pH}$ and conductivity result the low $Q$. In addition to the $\mathrm{pH}$ and conductivity, the operation time affects the performances of $\mathrm{Ni} / \mathrm{Ti}$ and $\mathrm{Ni} / \mathrm{GF}$. As shown in Figure 5, the optimum of operation time for Ni/Ti and Ni/GF were observed at 24 hours. Low $Q$ at 8 hours of operation time was due to the low protons supply. Meanwhile, Low $Q$ at 48 hours of operation time caused by the EAB activity was decreased at low pH. To better understand the effect of electrolyte conductivity on the $Q$, the further experiment should be performed. After 24 hours of MEC run, the $\mathrm{pH}$ and conductivity of anolyte were decreased, otherwise, the $\mathrm{pH}$ and conductivity of catholyte were increased (see Table 1). Also, type of substrate plays an important role to the EAB activity which contributes to the MEC performance. Based on the Table 4, simple substrate such as acetate was easier to generate hydrogen compared to complex substrate such as WW and FE.

\section{5 | Performance of Pt-based cathodes compared to $\mathrm{Ni} / \mathrm{Ti}$ and $\mathrm{Ni} / \mathrm{GF}$}

Commonly, the cathode performance is evaluated by measuring the several parameter such as the $\boldsymbol{r}_{\boldsymbol{H} \mathbf{2}[\boldsymbol{C a t}]}, \boldsymbol{n}_{\boldsymbol{E}}$, $I_{v}$, and $Q$. Overall, the $\mathrm{Ni} / \mathrm{Ti}$ and $\mathrm{Ni} / \mathrm{GF}$ performances were lower compared to that of Pt/GF, except the $\boldsymbol{n}_{\boldsymbol{E}}$ of $131.3 \pm 4.3 \%$ for Ni/Ti (Table 4). Meanwhile, the hydrogen compositions $(\mathrm{H} \%)$ of $\mathrm{Ni} / \mathrm{Ti}$ and $\mathrm{Ni} / \mathrm{GF}$ were obtained $68.6 \pm 0.6 \%$ and $55.6 \pm 2.4 \%$ respectively, which 


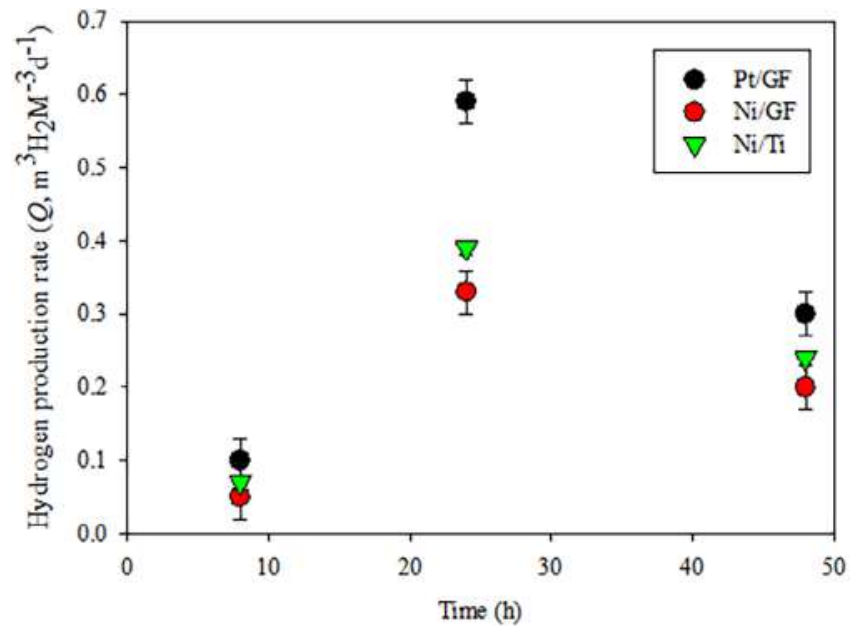

FI G URE 5 Trends of the maximum volumetric hydrogen production rates $(Q)$ of MEC for 48 hours of operation time. These $Q$ data were collected at the first month of experiment [Colour figure can be viewed at wileyonlinelibrary.com]

were lower compared to that of Pt metal $(74 \pm 2 \%)^{2}$ and $\mathrm{Pt} / \mathrm{GB}(74 \pm 4 \%) .{ }^{39}$ Increase in volume and hydrogen composition were positively related to increase in the applied voltage. For example, the hydrogen production and composition of $\mathrm{Pt} / \mathrm{GF}$ were obtained $18.2 \pm 1.2 \mathrm{~mL}$ and $23.2 \pm 2.1 \%$ (data not shown) at $0.6 \mathrm{~V}$ which were lower compared to $27.2 \pm 2.6 \mathrm{~mL}$ and $70.7 \pm 4.1 \%$ at $1.0 \mathrm{~V}$. This fact describes the additional voltage also plays a crucial role to the cathode performance. However, the higher voltage applied in the range of $1.0 \mathrm{~V}-1.2 \mathrm{~V}$ has no significant contribution to increase in the hydrogen production $(P>.05, t$ test). In this work, hydrogen production for $\mathrm{Pt} / \mathrm{GF}$ at $1.1 \mathrm{~V}$ and $1.2 \mathrm{~V}$ were $28.1 \pm 0.1$ and $28.3 \pm 0.1 \mathrm{~mL}$ respectively, while the hydrogen purities around $71 \%$. In many researches, the applied voltage in the range of $0.5-1.0 \mathrm{~V}$ is used in MEC system which was consistent with the applied voltage used in this study. Based on the substrate, however, the $Q$ of MEC with $\mathrm{Ni} / \mathrm{Ti}$ and $\mathrm{Ni} / \mathrm{GF}$ were much higher compared to that of SS using FE $\left(0.016 \mathrm{~m}^{3} \mathrm{H}_{2} \mathrm{~m}^{-3} \mathrm{~d}^{-1}\right)^{40}$ and NiMo/NF using WW $\left(0.13 \pm 0.01 \mathrm{~m}^{3} \mathrm{H}_{2} \mathrm{~m}^{-3} \mathrm{~d}^{-1}\right){ }^{17}$ This result indicates the feasibility of $\mathrm{Ni} / \mathrm{Ti}$ and $\mathrm{Ni} / \mathrm{GF}$ cathodes to generate hydrogen from real wastewater (ie, FE) was good. Overall, The $\mathrm{Ni} / \mathrm{Ti}$ and $\mathrm{Ni} / \mathrm{GF}$ show the promising performance to generate hydrogen from $\mathrm{FE}$ (as a real wastewater representative).

\section{4 | CONCLUSIONS}

The Ni/Ti and Ni/GF cathodes were prepared by using a simple method such as ED technique. Feasibility of $\mathrm{Ni} / \mathrm{Ti}$ and $\mathrm{Ni} / \mathrm{GF}$ were successfully evaluated for generating hydrogen from dark FE in MEC. Also, FE with a small $\mathrm{pH}$ modification (ie, $\mathrm{pH}=7.0$ ) could be reused as substrate to generate hydrogen. The efficiency of $\mathrm{Ni} / \mathrm{Ti}$ and $\mathrm{Ni} / \mathrm{GF}$ using $\mathrm{FE}$ substrate $\left(\boldsymbol{\eta}_{\mathrm{E}+\mathrm{s}}\right)$ were obtained $31 \%$ and $26 \%$, respectively. Low cost materials of $\mathrm{Ni} / \mathrm{Ti}$ and $\mathrm{Ni} / \mathrm{GF}$ show the promising performance in MEC. Due to FE could be assumed as a representation of real wastewater, the MEC with inexpensive cathodes could be applied toward real application. However, to declare the statement, the real wastewater must be used as substrate in MEC using Ni/Ti and Ni/GF cathodes in future works.

\section{ACKNOWLEDGEMENTS}

The authors gratefully acknowledge financial support given by the Universiti Kebangsaan Malaysia (UKM) via the research sponsorship of MI-2018-015 and the Ministry of Higher Education Malaysia via the research sponsorship of FRGS/2/2013/TK06/UKM/02/9. The authors would also like to acknowledge plagiarism check assistance by Assoc. Prof. Dr. Azrina Md Ralib of International Islamic University Malaysia (IIUM).

\section{ORCID}

Ibdal Satar (1) https://orcid.org/0000-0003-2721-2575

\section{REFERENCES}

1. Salembo PA, Merrill MD, Logan BE. Hydrogen production with nickel powder cathode catalysts in microbial electrolysis cells. Int J Hydrogen Energy. 2010;35:428-437.

2. Salembo PA, Merrill MD, Logan BE. The use of stainless steel and nickel alloys as low cost cathodes in microbial electrolysis cells. J Power Sources. 2009;190:271-278.

3. Li Y, Liu W, Zhang Z, Du X, Yu L, Deng Y. A self-powered electrolytic process for glucose to hydrogen conversion. Commun Chem. 2019;2(67):1-9.

4. Lu L, Ren ZJ. Microbial electrolysis cells for waste biorefinery: a state of the art review. Bioresour Technol. 2016;215: 254-264.

5. Marone A, Ayala-Campos OR, Trably E, et al. Coupling dark fermentation and microbial electrolysis to enhance biohydrogen production from agro-industrial wastewaters and byproducts in a bio-refinery framework. Int J Hydrogen Energy. 2017;42:1609-1621.

6. Wang A, Sun D, Cao G, et al. Integrated hydrogen production process from cellulose by combining dark fermentation, microbial fuel cells, and a microbial electrolysis cell. Bioresour Technol. 2011;102:4137-4143.

7. Ramírez-Vargas CA, Prado A, Arias CA, Carvalho PN, EsteveNúñez A, Brix H. Microbial electrochemical technologies for wastewater treatment: principles and evolution from microbial fuel cells to bioelectrochemical-based constructed wetlands. Water. 2018;10(1128):1-29.

8. Rozendal RA, Jeremiasse AW, Hamelers HVM, Buisman CJN. Hydrogen production with a microbial biocathode. Environ Sci Technol. 2007;42:629-634. 
9. Logan BE, Call D, Cheng S, et al. Microbial electrolysis cells for high yield hydrogen gas production from organic matter. Environ Sci Technol. 2008;42:8630-8640.

10. Logan BE, Cheng S, Watson V, Estadt G. Graphite fiber brush anodes for increased power production in air-cathode microbial fuel cells. Environ Sci Technol. 2007;41:3341-3346.

11. Cheng S, Logan BE. Sustainable and efficient biohydrogen production via electrohydrogenesis. Proc Natl Acad Sci U S A. 2007;104(47):18871-18873.

12. Liu H, Grot S, Logan BE. Electrochemically assisted microbial production of hydrogen from acetate. Environ Sci Technol. 2005;39(11):4317-4320.

13. Kundu A, Sahu JN, Redzwan G, Hashim MA. An overview of cathode material and catalysts suitable for generating hydrogen in microbial electrolysis cell. Int J Hydrogen Energy. 2013;38: 1745-1757.

14. Freguia S, Rabaey K, Yuan Z, Keller J. Non-catalyzed cathodic oxygen reduction at graphite granules in microbial fuel cells. Elecrochim Acta. 2007;53:598-603.

15. Sobrova P, Zehnalek J, Adam V, Beklova M, Kizek R. The effects on soil/water/plant/animal systems by platinum group elements. Cent Eur J Chem. 2012;10(5):1369-1382.

16. Vij V, Sultan S, Harzandi AM, et al. Nickel-based electrocatalysts for energy related applications: oxygen reduction, oxygen evolution, and hydrogen evolution reactions. ACS Catal. 2017;7(10):7196-7225.

17. Mitov M, Chorbadzhiyska E, Nalbandian L, Hubenova Y. Nickel-based electrodeposits as potential cathode catalysts for hydrogen production by microbial electrolysis. J Power Sources. 2019;xxx:1-6.

18. Jeremiasse AW, Hamelers HVM, Saakes M, Buisman CJN. Ni foam cathode enables high volumetric $\mathrm{H}_{2}$ production in a microbial electrolysis cell. Int J Hydrogen Energy. 2010;35: 12716-12723.

19. Tenca A, Cusick RD, Schievano A, Oberti R, Logan BE. Evaluation of low cost cathode materials for treatment of industrial and food processing wastewater using microbial electrolysis cells. Int J Hydrogen Energy. 2013;38:1859-1865.

20. Kadier A, Simayi Y, Chandrasekhar K, Ismail M, Kalil MS. Hydrogen gas production with an electroformed Ni mesh cathode catalysts in a single-chamber microbial electrolysis cell (MEC). Int J Hydrogen Energy. 2015;40(41):14095-14103.

21. Wang L, Li Y, Yin X, et al. Comparison of three nickel-based carbon composite catalysts for hydrogen evolution reaction in alkaline solution. Int J Hydrogen Energy. 2017;42:22655-22662.

22. Malaysia S-A. Catalysts and metals. www.sigmaaldrich.com/ malaysia. 2019. Accessed December 12, 2019.

23. Satar I, Daud WRW, Kim BH, Somalu MR, Ghasemi M. Immobilized mixed-culture reactor (IMcR) for hydrogen and methane production from glucose. Energy. 2017;139:11881196.

24. Satar I, Daud WRW, Kim BH, et al. Performance of titaniumnickel (Ti/Ni) and graphite felt-nickel (Ni/GF) electrodeposited by $\mathrm{Ni}$ as alternative cathodes for microbial fuel cells. J. Taiwan Inst. Chem. Eng. 2018;89:67-76.

25. Cheng S, Logan BE. Ammonia treatment of carbon cloth anodes to enhance power generation of microbial fuel cells. Electrochem Commun. 2007;9:492-496.
26. Liu H, Ramnarayanan R, Logan BE. Production of electricity during wastewater treatment using a single chamber microbial fuel cell. Environ Sci Technol. 2004;38:2281-2285.

27. Wang A, Liu W, Ren N, Zhou J, Cheng S. Key factors affecting microbial anode potential in a microbial electrolysis cell for $\mathrm{H}_{2}$ production. Int $J$ Hydrogen Energy. 2010;35:1348113487.

28. Lovley DR. The microbe electric: conversion of organic matter to electricity. Curr Opin Biotechnol. 2008;19:564-571.

29. Harnisch F, Schrçder U. Selectivity versus mobility: separation of anode and cathode in microbial bioelectrochemical systems. ChemSusChem. 2009;2:921-926.

30. Shinagawa T, Garcia-Esparza AT, Takanabe K. Insight on Tafel slopes from a microkinetic analysis of aqueous electrocatalysis for energy conversion. Sci Rep. 2015;5:13801.

31. Merrill MD, Logan BE. Electrolyte effects on hydrogen evolution and solution resistance in microbial electrolysis cells. J Power Sources. 2009;191:203-208.

32. Kyazze G, Popov A, Dinsdale R, et al. Influence of catholyte $\mathrm{pH}$ and temperature on hydrogen production from acetate using a two chamber concentric tubular microbial electrolysis cell. Int J Hydrogen Energy. 2010;35:7716-7722.

33. Cerrillo M, Viñas M, Bonmati A. Removal of volatile fatty acids and ammonia recovery from instable anaerobic digesters with a microbial electrolysis cell. Bioresour Technol. 2016;219: 348-356.

34. Logan BE. Feature article: biologically extracting energy from wastewater: biohydrogen production and microbial fuel cells. Environ Sci Technol. 2004;38:160A-167A.

35. Sarala P, Venkatesha TV. Effect of cathode materials on electrochemical degradation of Luganil Blue $\mathrm{N}$ and Acid Red I. Port Electrochim Acta. 2013;31:175-183.

36. Chen P-C, Chang Y-M, Wu P-W, Chiu YF. Fabrication of Ni nanowires for hydrogen evolution reaction in a neutral electrolyte. Int J Hydrogen Energy. 2009;34:6596-6602.

37. Kumar S, Pande S, Verma P. Factor effecting electro-deposition process. Int J Curr Eng Technol. 2015;5:700-703.

38. Sleutels THJA, Lodder R, Hamelers HVM, Buisman CJN. Improved performance of porous bio-anodes in microbial electrolysis cells by enhancing mass and charge transport. Int $J$ Hydrogen Energy. 2009;34:9655-9661.

39. Wagner RC, Regan JM, Oh SE, Zuo Y, Logan BE. Hydrogen and methane production from swine wastewater using microbial electrolysis cells. Water Res. 2009;43:1480-1488.

40. Chookaew T, Prasertsan P, Ren ZJ. Two-stage conversion of crude glycerol to energy using dark fermentation linked with microbial fuel cell or microbial electrolysis cell. $N$ Biotechnol. 2014;31(1):179-184.

41. Wang J, Wan W. Factors influencing fermentative hydrogen production: a review. Int $J$ Hydrogen Energy. 2009;34: 799-811.

42. Call DF, Logan BE. Hydrogen production in a single chamber microbial electrolysis cell lacking a membrane. Environ Sci Technol. 2008;42(9):3401-3406.

43. Ghasemi M, Daud WRW, Hassan SHA, et al. Carbon nanotube/polypyrrole nanocomposite as a novel cathode catalyst and proper alternative for Pt in microbial fuel cell. Int J Hydrogen Energy. 2015;41:4872-4878. 
44. Merrill MD. Water Electrolysis at the Thermodinamic Limit [doctoral dissertation]. Tallahassee, FL: Florida State University; 2007.

45. Sleutels THJA, Hamelers HVM, Rozendal RA, Buisman CJN. Ion transport resistance in microbial electrolysis cells with anion and cation exchange membranes. Int J Hydrogen Energy. 2009;34:3612-3620.

46. Yossan S, Xiao L, Prasertsan P, He Z. Hydrogen production in microbial electrolysis cells: choice of catholyte. Int J Hydrogen Energy. 2013;38:9619-9624.
How to cite this article: Satar I, Abu Bakar MH, Wan Daud WR, Mohd Yasin NH, Somalu MR, Kim BH. Feasibility of Ni/Ti and Ni/GF cathodes in microbial electrolysis cells for hydrogen production from fermentation effluent: A step toward real application. Int J Energy Res. 2020; 1-13. https://doi.org/10.1002/er.5466 


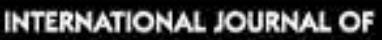 ENERGY RESEARCH}

\section{Volume 44, Issue 9}

Pages: i, 7105-7859

July 2020

〈Previous Issue | Next Issue >

ミ GO TO SECTION

"Export Citation(s)

\section{COVER IMAGE}

คैFree Access

\section{Cover Image}

Zengguang Sui, Jun Yang, Chengcheng Deng, Ye Yang

Pages: i | First Published: 23 June 2020
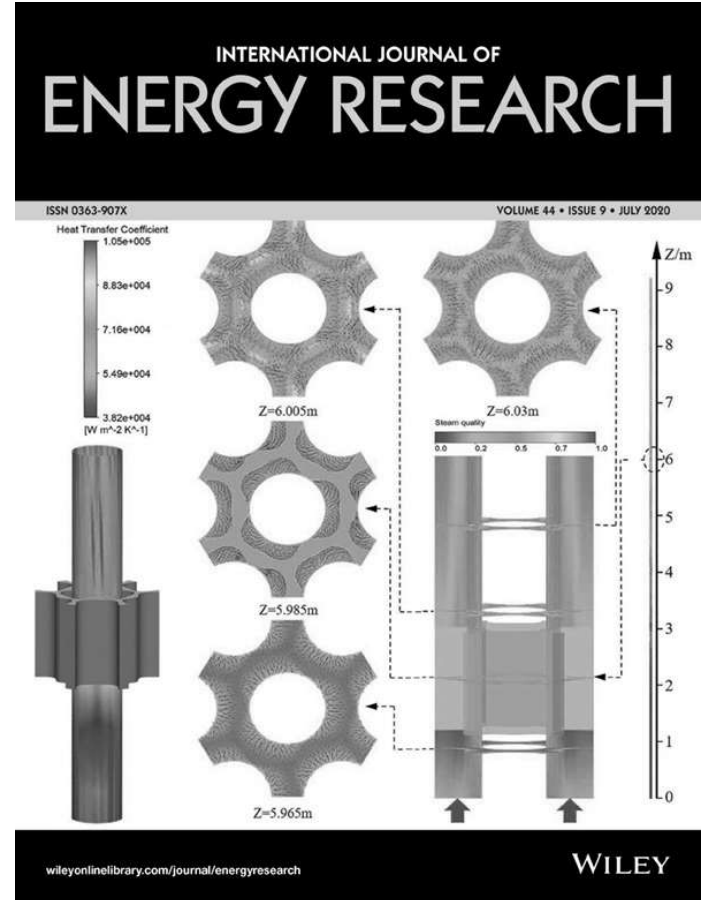

The cover image is based on the Research Article Numerical simulation of the effects of trefoil tube support plates on the flow and heat transfer characteristics of a steam generator by Zengguang Sui et al., https://doi.org/10.1002/er.5512. 
Abstract | PDF | Request permissions

\section{ISSUE INFORMATION}

?. Free Access

Issue Information

Pages: 7105-7107 | First Published: 23 June 2020

First Page | PDF | Request permissions

\section{REVIEW PAPERS}

Performance improvement of supercritical carbon dioxide power cycles through its integration with bottoming heat recovery cycles and advanced heat exchanger design: A review

Ramy H. Mohammed, Ali Sulaiman Alsagri, Xiaolin Wang

Pages: 7108-7135 | First Published: 31 March 2020

Abstract | Full text | PDF | References | Request permissions

Deep learning methods and applications for electrical power systems: A comprehensive review

Asiye K. Ozcanli, Fatma Yaprakdal, Mustafa Baysal

Pages: 7136-7157 | First Published: 30 March 2020

Abstract | Full text | PDF | References | Request permissions

Electrochemical impedance spectroscopy study of commercial Li-ion phosphate batteries: A metrology perspective

Lisa Deleebeeck, Sune Veltzé

Pages: 7158-7182 | First Published: 15 April 2020

Abstract | Full text | PDF | References | Request permissions 
Experimental investigation of a novel heat pipe thermoelectric generator for waste heat recovery and electricity generation

Simiao Tang, Chenglong Wang, Xiao Liu, Guanghui Su, Wenxi Tian, Suizheng Qiu, Qihao Zhang, Ruiheng Liu, Shengqiang Bai

Pages: 7450-7463 | First Published: 30 April 2020

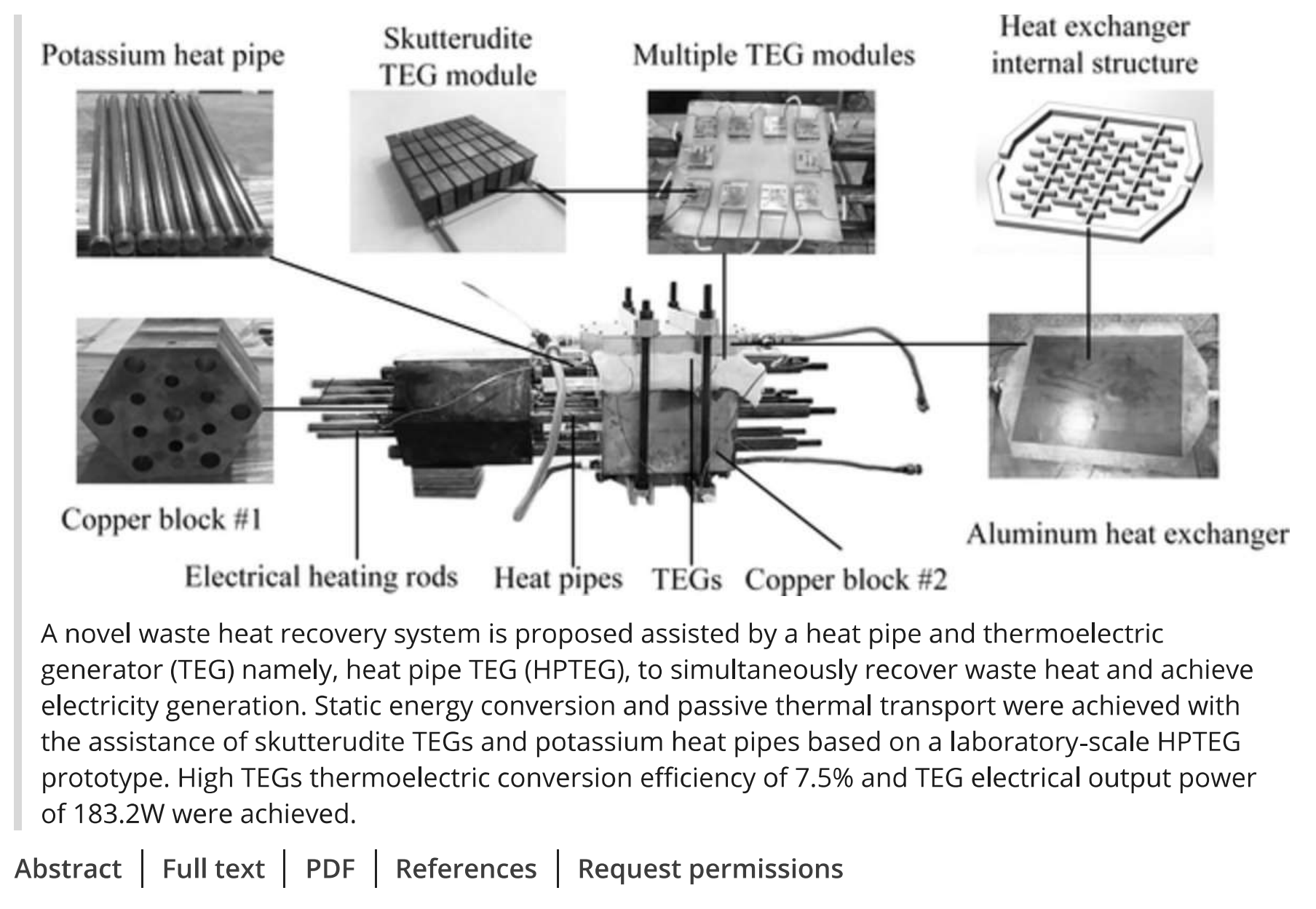

Feasibility of $\mathrm{Ni} / \mathrm{Ti}$ and $\mathrm{Ni} / \mathrm{GF}$ cathodes in microbial electrolysis cells for hydrogen production from fermentation effluent: A step toward real application

Ibdal Satar, Mimi Hani Abu Bakar, Wan Ramli Wan Daud, Nazlina Haiza Mohd Yasin, Mahendra Rao Somalu, Byung Hong Kim

Pages: 7464-7476 | First Published: 12 May 2020

Schematic of microbial electrolysis cell (MEC) for hydrogen production from dark fermentation effluent (FE). 


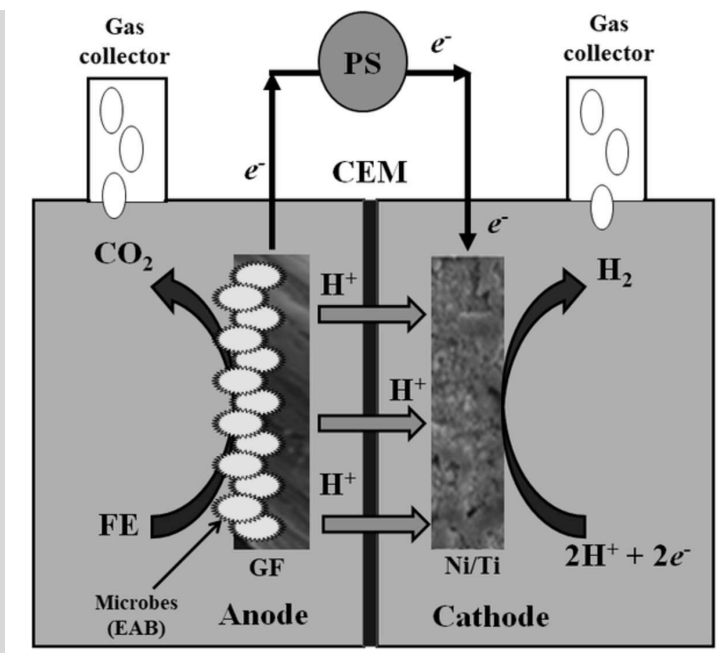

Abstract | Full text | PDF | References | Request permissions

Conceptual design for combined ocean thermal energy conversion using computational fluid dynamics and heat balance analysis

Eojin Jeon, Gyunyoung Heo, Iljin Kim, Hyungdae Kim, Hoon Jung

Pages: 7477-7494 | First Published: 22 April 2020
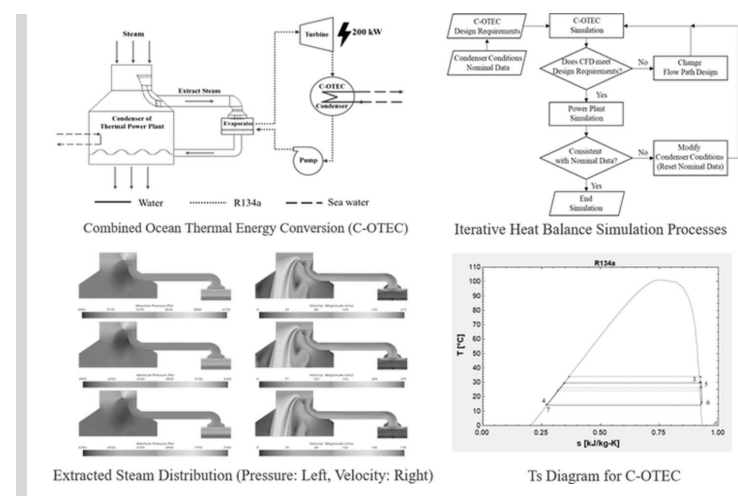

Abstract | Full text $\mid$ PDF $\mid$ References $\mid$ Request permissions
This paper introduced one of the new organic Rankine cycle applications, combined ocean thermal energy conversion (C-OTEC), which utilizes exhaust steam from a condenser of thermal power plant as a heat source. The technical feasibility of the $200 \mathrm{~kW}$ C-OTEC was examined using the method of interactive heat balance simulation and computational fluid dynamics. We also provided the quantitative pros and cons on the performance of existing thermal power plants while installing a large-scale C-OTEC.

\section{Efficient model predictive control for real-time energy optimization of battery-} supercapacitors in electric vehicles

Shiming Yu, Di Lin, Zhe Sun, Defeng He

Pages: 7495-7506 | First Published: 28 April 2020

Abstract | Full text | PDF | References | Request permissions 
INTERNATIONAL JOURNAL OF

ENERGY RESEARCH

\section{Editor-in-Chief:}

\section{Professor I. Dincer}

Faculty of Engineering and Applied Science, University of Ontario Institute of Technology (UOIT), 2000 Simcoe Street North, Oshawa, Ontario L1H 7K4, Canada

Email: lbrahim.Dincer@uoit.ca

\section{Associate Editors:}

\section{Professor Wei-Hsin Chen}

Department of Aeronautics and Astronautics, National Cheng Kung University, Tainan, Taiwan Email: chenwh@mail.ncku.edu.tw

\section{Professor Tatiana Morosuk}

Chair of Exergy-based Methods for Refrigeration Systems, Technische Universität Berlin, Berlin, Germany

Email: tetyana.morozyuk@tu-berlin.de

\section{Professor Meng Ni}

Department of Building and Real Estate, The Hong Kong Polytechnic University, Hong Kong Email: meng.ni@polyu.edu.hk

\section{Professor Sandro Nizetic}

LTEF - Laboratory for Thermodynamics and Energy Efficiency, Faculty of Electrical Engineering, Mechanical Engineering and Naval Architecture, University of Split, Croatia

Email: snizetic@fesb.hr

\section{Professor Ramazan Solmaz}

Bingöl University, Turkey

Email: rsolmaz01@gmail.com

\section{Professor Xin-Rong Zhang}

Department of Energy \& Resources Engineering, Peking Univeristy, Beijing, China

Email: xrzhang@pku.edu.cn

\section{Honorary Editor:}


Professor J. T. McMullan

Woodbridge, Suffolk, U.K.

Editorial Board:

Professor M. Ahmed

Egypt-Japan University of Science and Technology (E-JUST)

Egypt

\section{Professor M. Assadi}

University of Stavanger

Norway

Professor A. Bejan

Duke University

Durham

U.S.A

Professor W. Chun

Cheju National University

Korea

Professor M. Gadalla

American University of Sharjah

United Arab Emirates

Professor V. Edwin Geo

SRM Institute of Science and Technology

India

\section{Professor F. Aloui}

University of Valenciennes

France

Professor S. Basu

Department of Chemical Engineering I.I.T. Delhi India

Professor S.H. Chan

Nanyang Technological University

Singapore

\section{Professor W. D'Haeseleer}

University of Leuven Energy Institute

Belgium

Professor N. Ghaddar

American University of Beirut

Lebanon

Dr P. Grammelis

Centre for Research \& Technology Hellas

Institute for Solid Fuels Technology \& Applications

(CERTH/ISFTA)

Athens, Greece

Professor A. Hepbasli

Yaşar University

Turkey

Professor M. Kaltschmitt

Hamburg University of Technology

Germany
Professor S. Harvey

Gothenburg

Sweden

Professor Y.H. Hu

Michigan Technological University

U.S.A. 
Dr J. W. Kim

Hydrogen Energy R\&D Center, Daejeon

Republic of Korea

Professor P. Mago

West Virginia University

USA

Professor B. G. Pollet

Norwegian Univeristy of Science and Technology

Norway

Professor S. B. Riffat

University of Nottingham

United Kingdom

Professor M. Santarelli

Politecnico di Torino

Italy

Dr C. W. Tong

University of Malaya

Malaysia

Professor J.V.C. Vargas

Universidade Federal do Parana

Brazil
Professor X. Li

University of Waterloo

Canada

Professor G.F. Naterer

Memorial University

Newfoundland, Canada

\section{Professor A. Heitor Reis}

University of Evora

Portugal

\author{
Dr M. Romero \\ IMDEA Energía \\ Spain
}

Professor L.K. Teong

Universiti Sains Malaysia

Malaysia

Professor G. Tsatsaronis

Technische Universität Berlin

Germany

Professor G. Xie

Northwesterm Polytechnical University

Xi'an, China

Tools

a Submit an Article

Get content alerts

- Subscribe to this journal 
Related Title: New for 2019

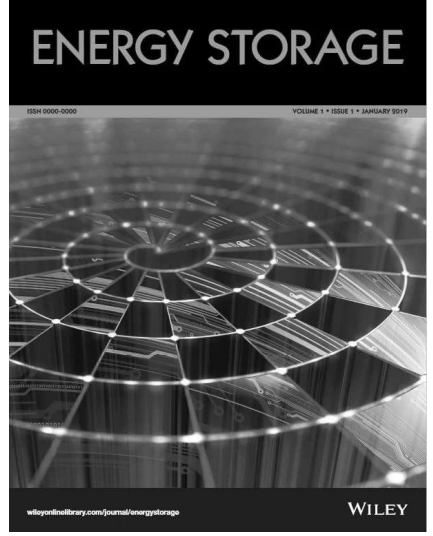

More from this journal

More Energy Journals

To Our Authors Newsletter

Special Issues

LaTeX class file

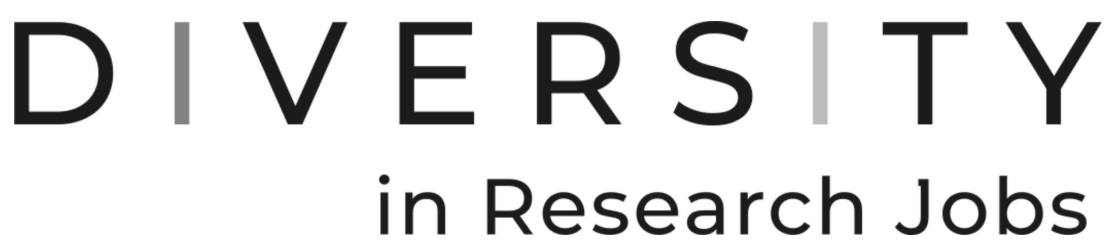

Please contact us to see your job listed here

\section{Environmental Fate Specialist/Modeller}

\section{Heidelberg $\mid € 60000-€ 70000$ per annum + pension and benefits}

Environmental fate specialist for a independent scientific consultancy for registration of chemical and biological plant protection products

Employer: NonStop Consulting

\section{Section Head - Ecotoxicologist}

Homeworking | remotely based

Agrochemical consultancy looking for an experience ecotoxicologist to lead department of international ecotoxicologists

Employer: NonStop Consulting

Principal/Associate Geotechnical Engineer

a. . . I numana namana

Related Titles 


\author{
About Wiley Online Library \\ Privacy Policy \\ Terms of Use \\ Cookies \\ Accessibility \\ Help \& Support \\ Contact Us \\ Opportunities \\ Subscription Agents \\ Advertisers \& Corporate Partners \\ Connect with Wiley \\ The Wiley Network \\ Wiley Press Room
}

Copyright (c) 1999-2021 John Wiley \& Sons, Inc. All rights reserved 